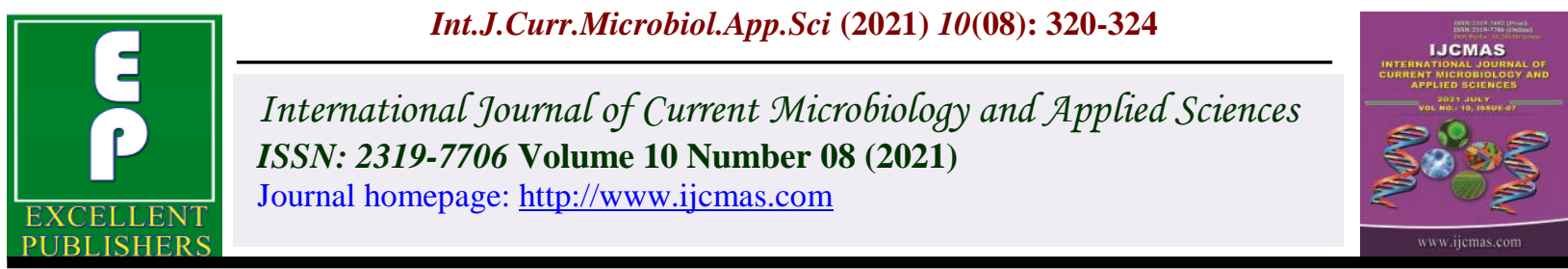

\title{
Supplementation of Asparagus Racemosus (Shatavari) on Immune Parameters in Giriraja Birds
}

\author{
N. Bharath Kuman ${ }^{1 *}$, H. C. Indresh ${ }^{1}$, T. N. Krishnamurthy ${ }^{2}$ and Jayanaik $^{1}$ \\ ${ }^{1}$ Department of Poultry Science, Veterinary College, Hebbal, Bangalore, India \\ ${ }^{2}$ Department of Livestock Production Management, Veterinary College, Shivamogga, India \\ *Corresponding author
}

\section{A B S T R A C T}

\section{Keywords}

Infectious Bursal disease, Immune response, Newcastle disease, Giriraja poultry birds

Article Info

Accepted:

15 July 2021

Available Online:

10 August 2021
An experiment was conducted to study the supplementation of Asparagus racemosus (SHATAVARI) on immune parameters in Giriraja birds. A total of one hundred and fifty day- old chicks were distributed into five treatment groups with three replicates in each group and ten birds in each replicate. Basal diet $\left(T_{1}\right)$ and the experimental diets were prepared by incorporating Shatavari at 0.25 per cent $\left(\mathrm{T}_{2}\right)$, Shatavari at 0.50 per cent $\left(\mathrm{T}_{3}\right)$, Shatavari at 1.0 per cent $\left(\mathrm{T}_{4}\right)$ and Shatavari at 1.50 per cent $\left(\mathrm{T}_{5}\right)$. The duration of the experiment was 8 weeks. Blood samples was collected from two birds from each replicate on $56^{\text {th }}$ day. Serum was separated and antibody titer against Newcastle disease virus and Infectious bursal disease virus was estimated using HA followed by HI (Allan and Gough, 1974) and using indirect ELISA kit. The immune response against Newcastle disease at various levels of Asparagus racemosus supplemented groups had no significant $(\mathrm{P}>0.05)$ difference in titre values among the treatment groups when compared to the control. The immune response against Infectious bursal disease at various levels of Asparagus racemosus supplemented groups showed significantly $(\mathrm{P} \leq 0.05)$ higher titre values among the treatment groups when compared to the control. It was concluded that supplementation of Asparagus racemosus at 1.0 per cent had higher titre value in immuneresponse against Infectious bursal disease on $56^{\text {th }}$ day of the experiment. No significant $(\mathrm{P}>0.05)$ difference showed in immuneresponse against Newcastle disease in Asparagus racemosus supplemented groups compared to control.

\section{Introduction}

In poultry production, feed consumption plays a major role in affecting net return from the poultry because about 65 to 70 per cent of the total expenditure in terms of cash is spent on feed. Over a period of time extensive efforts have been taken to lower down the cost of production by lowering the expenses on feed. In the past, the major growth promoters were antibiotics used as antibiotic growth promoters (AGP) have been helpful in improvement of 
growth performance and feed conversion ratio in poultry (Miles et al., 2006). However, constant treatment of poultry by antibiotics may result in residues of these substances in poultry products and bacterial resistance against treatments in the human body. Due to such threats to human health, use of antibiotics in poultry is banned in many countries (Owens et al., 2008). To ensure more net return and to lessen the adverse effect of the synthetic feed additives on animal as well as on consumer's health; many of the herbal growth promotors are being used as an alternative feed additive in the poultry ration. There is also some evidence from the earlier workers that the use of commercial blends of herbs can reduce the cost of poultry production and increase in body weight (Majdanski, 1991).

Asparagus racemosus (Shatavari) is the one of the most commonly used herbs in traditional medicine due to the presence of steroidal saponins and sapogenins in various part of the plant (Krishna et al., 2005). In Ayurveda this herb is known as the "Queen of Herbs". Traditionally it is used as a health tonic (Pandey, 1998). Parts used of this plant are roots (Rhizome) and leaves. Asparagus racemosus is used for preventing ageing, increase longevity, impart immunity, improve mental function, nervous disorders, dyspepsia, tumors, inflammation, neuropathy and hepatopathy. Most of the literature review showed that root extract of Asparagus racemosus has antiulcer activity, antioxidant, anti-diarrhoeal, anti-diabetic and immunemodulatory activities (Shukla et al., 2018).

The beneficial effects of Asparagus racemosus may be attributed toits concentrations of saponins (active principle), known as Shatavarins and having properties like nutritive tonic and anti-stress effects (Kamat et al., 2000). The root powder of Asparagus racemosus is used as herbal feed additive or supplement in poultry feed. Asparagus racemosus augment the appetite and stimulates the liver function. Sharma et al., (1986) showed that Asparagus racemosus possess anabolic properties viz. growth promotion, laxative, antacid and appetizer beneficial.

\section{Materials and Methods}

The experiment was conducted at the Department of Poultry Science, Veterinary College, Hebbal, Bengaluru. A total of 150 one day old Giriraja birds were distributed into five treatment groups with three replicates in each group and ten birds in each replicate. Chicks were reared under deep litter system with supply of ad libitum feed and water. The trial duration was for 8 weeks (56 days). A standard broiler pre-starter, starter and finisher rations were formulated as per BIS (2007) recommendation. Basal diet $\left(\mathrm{T}_{1}\right)$ and the experimental diets were prepared by incorporating Shatavari at 0.25 per cent $\left(\mathrm{T}_{2}\right)$, Shatavari at 0.50 per cent $\left(\mathrm{T}_{3}\right)$, Shatavari at 1.0 per cent $\left(\mathrm{T}_{4}\right)$ and Shatavari at 1.50 per cent $\left(\mathrm{T}_{5}\right)$. Standard managemental practice was followed during the experiment. Blood samples was collected from two birds from each replicate on $56^{\text {th }}$ day. Serum was separated and antibody titer against Newcastle disease virus and Infectious bursal disease virus was estimated using HA followed by HI (Allan and Gough, 1974) and using indirect ELISA kit. At the end of the experiment, two birds from each replicate in each treatment groups were slaughtered to record the weight of lymphoid organs viz., spleen, thymus and bursa of fabricius.

\section{Results and Discussion}

\section{Immunological parameters}

The immune response against Newcastle disease at various levels of Asparagus 
racemosus supplemented groups showed in Table 1 had no significant $(\mathrm{P}>0.05)$ difference in titre values among the treatment groups when compared to the control.

The immune response against Infectious bursal disease at various levels of Asparagus racemosus supplemented groups showed significantly $(\mathrm{P} \leq 0.05)$ higher titre values among the treatment groups when compared to the control. However, mean antibody titre against IBDV was significantly higher in the group which was supplemented with 1.0 per cent Asparagus racemosus. The result of present study is corroborate with findings of Durrani et al., 2007; Tekade et al., 2008; Ashwini et al., 2019; The higher immunity in supplementation of Asparagus racemosus in birds due to higher nutrient utilisation efficiency, which in turn might have triggered immunogenic cells to record higher immune response. The reason is due to the increased activity of neutrophils in blood after vaccination play a major role to improve high IBD titre value. The lymphoid organs weight
(\% of live weight) at various levels of Asparagus racemosus supplemented groups showed in table 2 revealed significant $(\mathrm{P} \leq 0.05)$ increase in weight of bursa of fabricius when compared to control group. No significant $(\mathrm{P}>0.05)$ difference was observed in weight of spleen and thymus among various levels of Asparagus racemosus supplemented groups when compared to control group. The weight of bursa of fabricius was recorded highest in 1.0 per cent Asparagus racemosus supplemented group.

The use of herbal supplements, Shatavari root powder were found to be beneficial in Giriraja poultry bird for its encouraging results in relation to immune parameters. Supplementation of Asparagus racemosus at 1.0 per cent had higher titre value in immune response against Infectious bursal disease on 56th day of the experiment. No significant ( $\mathrm{P}$ $>0.05)$ difference showed in immune response against Newcastle disease in Asparagus racemosus supplemented groups compared to control.

Table.1 Supplementation of Asparagus racemosus on antibody titres against Newcastle disease $\left(\log _{10} \mathrm{HI}\right.$ titre) and Infectiousbursal disease (ELISA) in Giriraja birds.

\begin{tabular}{|c|c|c|c|}
\hline $\begin{array}{l}\text { Experimental } \\
\text { group }\end{array}$ & Description of the treatment & NDV & IBDV titre \\
\hline $\mathbf{T}_{1}$ & Basal diet & $\begin{array}{c}1.304 \pm \\
0.30\end{array}$ & $\begin{array}{l}1559.43 \pm \\
288.30^{b}\end{array}$ \\
\hline $\mathbf{T}_{2}$ & $\begin{array}{c}\text { Basal diet }+0.25 \text { per centAsparagus } \\
\text { racemosus }\end{array}$ & $\begin{array}{l}1.391 \pm \\
0.17\end{array}$ & $\begin{array}{l}1562.71 \pm \\
163.80^{\mathrm{b}}\end{array}$ \\
\hline $\mathbf{T}_{\mathbf{3}}$ & $\begin{array}{r}\text { Basal diet }+0.5 \text { per cent Asparagus } \\
\text { racemosus }\end{array}$ & $\begin{array}{l}1.414 \pm \\
0.12\end{array}$ & $\begin{array}{c}1584.66 \pm \\
359.71^{\mathrm{b}}\end{array}$ \\
\hline $\mathbf{T}_{4}$ & $\begin{array}{c}\text { Basal diet }+1.0 \text { per cent Asparagus } \\
\text { racemosus }\end{array}$ & $\begin{array}{l}1.396 \pm \\
0.22\end{array}$ & $\begin{array}{c}2498.88 \pm \\
231.06^{\mathrm{a}}\end{array}$ \\
\hline $\mathbf{T}_{5}$ & $\begin{array}{r}\text { Basal diet }+1.5 \text { per cent Asparagus } \\
\text { racemosus }\end{array}$ & $\begin{array}{l}1.417 \pm \\
0.18\end{array}$ & $\begin{array}{c}2413.56 \pm \\
291.49^{\mathrm{a}}\end{array}$ \\
\hline
\end{tabular}

${ }^{\mathrm{a}, \mathrm{b}}$ Means in the same column with no common superscript differ significantly $(\mathrm{P} \leq 0.05)$ 
Table.2 Supplementation of Asparagus racemosus on lymphoid organs weight (\% of live weight) (Mean \pm SE) in Giriraja birds

\begin{tabular}{|c|c|c|c|c|}
\hline \multirow{2}{*}{$\begin{array}{c}\text { Experimental } \\
\text { group }\end{array}$} & Description of the treatment & \multicolumn{3}{|c|}{$\begin{array}{c}\text { Lymphoid organs weight } \\
\text { (g/100g body weight) }\end{array}$} \\
\cline { 3 - 5 } & & Spleen & $\begin{array}{c}\text { Bursa of } \\
\text { Fabricius }\end{array}$ & Thymus \\
\hline $\mathbf{T}_{\mathbf{1}}$ & Basal diet & $0.124 \pm 0.150$ & $0.131 \pm 0.014^{\mathrm{b}}$ & $0.340 \pm 0.047$ \\
\hline $\mathbf{T}_{\mathbf{2}}$ & $\begin{array}{c}\text { Basal diet }+0.25 \text { per cent } \\
\text { Asparagus racemosus }\end{array}$ & $0.119 \pm 0.009$ & $0.142 \pm 0.004^{\mathrm{b}}$ & $0.333 \pm 0.017$ \\
\hline $\mathbf{T}_{\mathbf{3}}$ & $\begin{array}{c}\text { Basal diet }+0.5 \text { per cent } \\
\text { Asparagus racemosus }\end{array}$ & $0.133 \pm 0.019$ & $0.139 \pm 0.009^{\mathrm{b}}$ & $0.317 \pm 0.027$ \\
\hline $\mathbf{T}_{\mathbf{4}}$ & $\begin{array}{c}\text { Basal diet }+1.0 \text { per cent } \\
\text { Asparagus racemosus }\end{array}$ & $0.131 \pm 0.107$ & $0.193 \pm 0.008^{\mathrm{a}}$ & $0.315 \pm 0.047$ \\
\hline $\mathbf{T}_{\mathbf{5}}$ & $\begin{array}{c}\text { Basal diet }+1.5 \text { per cent } \\
\text { Asparagus racemosus }\end{array}$ & $0.128 \pm 0.009$ & $0.197 \pm 0.006^{\mathrm{a}}$ & $0.304 \pm 0.040$ \\
\hline
\end{tabular}

${ }^{a, b}$ Means in the same column with no common superscript differ significantly $(\mathrm{P} \leq 0.05)$

Supplementation of Asparagus racemosus at 1.0 per cent had improvement in weight of bursa of fabricius compared to other treatment groups and control whereas spleen and thymus weight showed no significant $(\mathrm{P}>0.05)$ difference among different treatment groups when compared to control group at the end of the experiment (56th day).

\section{References}

Allan, W. H. and Gough, R. E., 1974. A standard haemagglutination inhibition test for Newcastle disease (2) Vaccination and challenge. The Veterinary Record, 95(7): 147-149.

Ashwini, S., Munegowda, T., Indresh, H. C., Vidyasagar, vijay, D. and Sayyad, I. A., 2019. Effect of supplementation of phytobioticshatavari (Asparagus racemosus) on the growth performance and carcass characteristics in raja II broilers.J. Entomol. Zool. Stud., 7(2): $519-523$

BIS (2007). Bureau of Indian Standards. Livestock feed and equipment systems sectional committee, FAD 5.

Durrani, F. R., Sultan. A., Marri. M. L.,
Chand. N. and Durrani. Z., 2007. Effect of herbal extract Infusion on the overall performance of broiler chicks. Pakistan J. Biol. Sci.,10(7): 1130 1133

Kamat, J. P., Boloor, K. K., Devasagayam, T. P. and Venkatachalam, S. R., 2000. Antioxidant properties of Asparagus racemosus against damage induced by gamma-radiation in rat liver mitochondria. J.Ethnopharmacol., 71(3): 425 - 435

Krishna, L., Swarup, D. and Patra, R. C., 2005. An overview of prospects of ethno-veterinary medicine in India. Indian J. Anim. Sci., 75: 1481 - 1491

Majdanski, F., 1991. Herbal feed additive in feeding broilers. African J. Agric. Res.,48: 67 - 73

Miles, R. D., Gutcher, G. D., Henry, P. R. and Littell, R. C., 2006. Effect of antibiotic growth promoters on broiler performance, intestinal growth parameters and quantitative morphology. Poult. Sci., 85: 476 - 485

Owens, B., Tucker, L., Collins, M. A. and Mccracken, K. J., 2008. Effects of different feed additives alone or in 
combination on broiler performance, gut microflora and ileal histology. Brit. Poult. Sci., 49: 202 - 212

Pandey, G. S., 1998. Nighantu KCBP, Chaukhamkhabharati academy: Varanasi, India. 392 -393

Sharma, S., Dahanukar, S. and Karandikar, S. M., 1986. Effects of long-term administration of the roots of Ashwagandha (Withania somnifera) and Shatavari (Asparagus racemosus) in rats. Indian Drugs., 23: 133 - 139
Shukla, P. K., Yadav, B. K. and Bhattacharyya, A., 2018. Utilization of Shatavari meal in poultry feed. Int. J. Avian Wildl. Biol., 3: $432-434$

Tekade, S. H., Mode, S. G. and Waghmare, S. P., 2008. Effect of Asparagus racemosus, Sida cordifolia and levamisole on immunological parameters in experimentally induced immunosuppresed broilers. Vet.world., 1(2): 49 - 50

\section{How to cite this article:}

Bharath Kuman, N., H. C. Indresh, T. N. Krishnamurthy and Jayanaik. 2021. Supplementation of Asparagus Racemosus (Shatavari) on Immune Parameters in Giriraja Birds. Int.J.Curr.Microbiol.App.Sci. 10(08): 320-324. doi: https://doi.org/10.20546/ijcmas.2021.1008.037 